\title{
Rola intensywnych opadów burzowych w transformacji rzeźby Karpat (na przykładzie zdarzenia z czerwca 2009 r. na Podhalu)
}

\author{
The role of extreme falls of rain in the transformation of Carpathian relief \\ (a case study from Poland's Podhale region, June 2009)
}

\author{
MICHAŁ DEUGOSZ \\ Instytut Geografii i Przestrzennego Zagospodarowania im. S. Leszczyckiego PAN, \\ 31-018 Kraków, św. Jana 22; długosz@zg.pan.krakow.pl
}

\begin{abstract}
Zarys treści. Pod koniec czerwca 2009 r. w południowej Polsce wystąpił szereg lokalnych ulew typu burzowego, których efektem były lokalne wezbrania na rzekach i potokach zlewni górnej Wisły. Nastąpiło przekroczenie stanów ostrzegawczych, a w niektórych przypadkach alarmowych na małych potokach i rzekach.

Opady notowane w Małopolsce w dniach 22-28 czerwca charakteryzowała wysoka suma i duże natężenie oraz bardzo nieregularny rozkład czasowo-przestrzenny. Spośród sum dobowych opadów notowanych w zlewni Dunajca w przyjętym okresie zdecydowanie wyróżnia się opad o sumie $140 \mathrm{~mm}$ z 28 czerwca, zanotowany na stacji w Witowie. Opracowanie zawiera opis morfologicznych skutków tego zdarzenia.
\end{abstract}

Słowa kluczowe: opad burzowy, powódź, procesy morfogenetyczne, Karpaty, Podhale.

\section{Wstęp}

Opady atmosferyczne należą do głównych czynników warunkujących współczesne procesy morfogenetyczne w obszarach górskich. Rodzaj, wielkość oraz intensywność tych procesów zależy od typu opadów, w tym od sumy i natężenia oraz od czasu ich trwania. Istotne są również pozostałe uwarunkowania środowiskowe, takie jak budowa geologiczna obszaru, rzeźba i użytkowanie terenu.

Decydująca rola opadów atmosferycznych w przekształcaniu rzeźby dotyczy również łańcucha Karpat. Zainteresowanie badaczy tym problemem zaowocowało szeregiem publikacji opisujących morfologiczne efekty opadów różnego rodzaju w obszarach o różnych typach rzeźby. Krótkotrwałe, intensywne opady o wysokiej sumie i natężeniu wywołują na stokach wysokogórskich spływy gruzowe (min. Nemćok, 1982; Midriak, 1984; Kotarba, 1992, 1998, 2002; Łajczak 
i Migoń, 2007), a w obszarach fliszowych średniogórskich i pogórskich - spłukiwanie na stokach (Długosz i Gębica, 2008) oraz spływy błotne (Ziętara, 1968; Długosz, 2009; Gorczyca i Wrońska-Wałach, 2008; Bucała, 2009). Opady atmosferyczne o mniejszej intensywności i dłuższym czasie trwania, lecz o większych sumach powodują uruchomienie płytkich zsuwów zwietrzeliny, odmłodzenie starych osuwisk oraz duże przekształcenia w korytach rzek (min. Jakubowski, 1965; Gil i Starkel, 1979; Thiel, 1989; Gil, 1997; Rączkowski i Mrozek, 2002; Gorczyca, 2004; Cebulak i inni, 2009; Micu i Balteanu, 2009).

W licznych pracach z zakresu geomorfologii podejmowano próby wyznaczenia wartości progowych opadów inicjujących procesy morfogenetyczne (m.in. Caine, 1980; Govi i inni, 1982; Krzemień, 1988; Kotarba, 1994; Glade, 1998; Gil i Długosz, 2006; Gil i inni, 2009). L. Starkel (1996) wytypował 3 rodzaje opadów, w czasie których dochodzi do przekroczenia wartości progowych na obszarze Karpat. Krótkotrwałe ulewy o natężeniu 1-3 $\mathrm{mm} \mathrm{min}^{-1}$ prowadzą do uruchomienia spłukiwania, spływów błotnych, a na obszarze Tatr spływów gruzowych. Opady rozlewne rzędu $140-500 \mathrm{~mm}$ w ciągu 2-5 dni powodują powstawanie płytkich zsuwów zwietrzelin, odmłodzenie starych powierzchni osuwiskowych oraz przekształcenie systemu korytowego. Pory deszczowe o opadach miesięcznych 100-500 mm wpływają na nasycenie podłoża wilgocią i sprzyjają uruchomieniu głębokich osuwisk skalnych.

Niniejsze opracowanie ma na celu przedstawienie skutków morfologicznych opadu atmosferycznego, który miał miejsce 28 czerwca 2009 r. w Witowie na Podhalu oraz pokazanie roli tego typu zdarzeń w transformacji rzeźby Karpat. Z uwagi na wysoką sumę i krótki czas trwania opad ten można zaliczyć do ulewnych.

\section{Obszar badań}

Ekstremalne zdarzenie opadowe z czerwca 2009 r. miało miejsce w rejonie wsi Witów, położonej w obrębie Pogórza Gubałowskiego, na Podhalu, w Karpatach polskich (ryc. 1). Rzeźba Pogórza Gubałowskiego ma charakter niskich gór i pogórzy o szerokich spłaszczonych wierzchowinach opadających w kierunku północnym. Wysokości bezwzględne nieznacznie przekraczają tu $1200 \mathrm{~m} \mathrm{npm.,}$ deniwelacje dochodzą do $530 \mathrm{~m}$. Doliny mają głębokość od 200 do $300 \mathrm{~m}$. Długość stoków o profilu wypukłym lub wypukło-wklęsłym nie przekracza $2 \mathrm{~km}$. Dominują stoki o nachyleniu 3-8 oraz 9-14 (Długosz, 2009).

Pogórze Gubałowskie budują warstwy fliszu podhalańskiego, o prostej w porównaniu do fliszu Karpat zewnętrznych budowie geologicznej. Na badanym obszarze dominują piaskowcowo-łupkowe i piaskowcowe warstwy chochołowskie dolne oraz piaskowce i bentonity warstw chochołowskich górnych (Badak, 1964). Wymienione warstwy charakteryzuje niewielki upad - 0-10. 


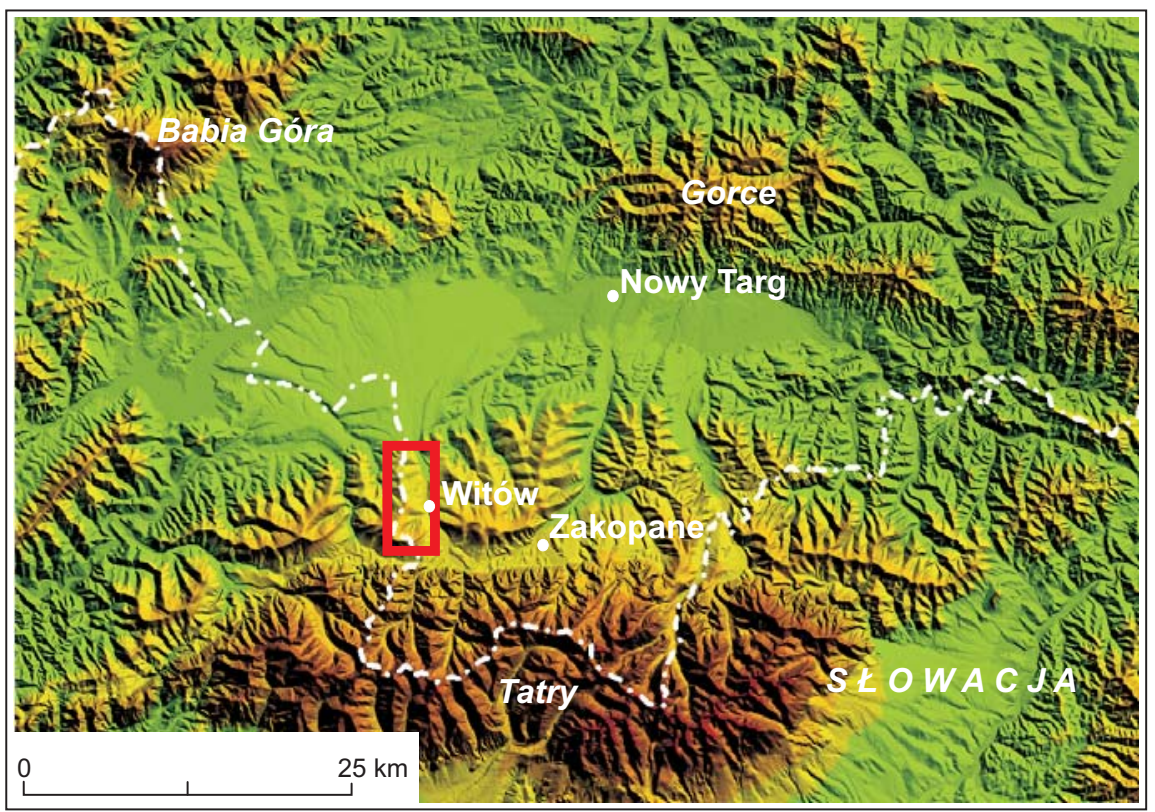

Ryc. 1. Położenie obszaru badań na tle wysokościowego modelu Polski (DTM), Uniwersytet Śląski

Location of the study area on the background of the Digital Terrain Model (DTM) by the Silesian University

Ekstremalny opad z dnia 28 czerwca 2009 r. objął swym zasięgiem głównie zachodnie zbocza doliny Dunajca między wsiami Witów i Chochołów. Szczegółowymi badaniami geomorfologicznych skutków opadu objęto obszar o powierzchni blisko $12 \mathrm{~km}^{2}$, rozciągający się od szczytu Magury Witowskiej do wzniesienia Beskidu (ryc. 3). Zachodnią granicę stanowiła linia grzbietowa, a wschodnią dolina Dunajca.

\section{Metoda badań}

Badania terenowe, polegające na kartowaniu geomorfologicznym skutków opadu atmosferycznego, przeprowadzono w lipcu 2009 r. Kartowanie wykonano na mapach topograficznych w skali 1:10 000, na które nanoszono formy powstałe w następstwie opadu. Wykorzystano odbiornik GPS, taśmę mierniczą oraz busolę. Kartowaniem szczegółowym objęto pięć dolin bocznych rozcinających stoki doliny Czarnego Dunajca. Sporządzono profile podłużne wymienionych dolin i zaznaczono na nich strefy morfodynamiczne. W obrębie wyznaczonych stref określono również frakcję maksymalną materiału transportowanego w korycie. 
Pomocne w badaniach terenowych i w interpretacji ich wyników były materiały zebrane $\mathrm{w}$ trakcie kartowania osuwisk $\mathrm{w}$ ramach realizacji pracy doktorskiej. Wykorzystano mapę osuwisk oraz dołączoną do niej bazę danych sporządzoną w trakcie badań terenowych we wrześniu 2007 r. (Długosz, 2009).

\section{Opady burzowe w Małopolsce w czerwcu 2009 r.}

Pod koniec czerwca 2009 r. w południowej Polsce wystąpił szereg zdarzeń opadowych, których efektem były lokalne wezbrania na rzekach i potokach zlewni górnej Wisły. Wezbrania te były skutkiem nie długotrwałych opadów, lecz lokalnych ulew typu burzowego i cechowały się wysoką sumą, dużym natężeniem oraz bardzo nieregularnym rozkładem czasowo-przestrzennym (ryc. 2).

Spośród sum dobowych opadów notowanych w zlewni Dunajca w II połowie czerwca 2009 r. zdecydowanie wyróżnia się opad z 28 czerwca, zarejestrowany na stacji w Witowie, o wysokości $140 \mathrm{~mm}$ (Analiza powodzi..., 2009). Brak dokładnych danych o czasie trwania i natężeniu opadu, ale na podstawie form powstałych w jego następstwie można wnioskować o jego dużej intensywności. Zasięg przestrzenny wysokich opadów był niewielki, o czym świadczą dobowe sumy opadów z posterunków sąsiednich (tab. 1, ryc. 2). Stacje opadowe

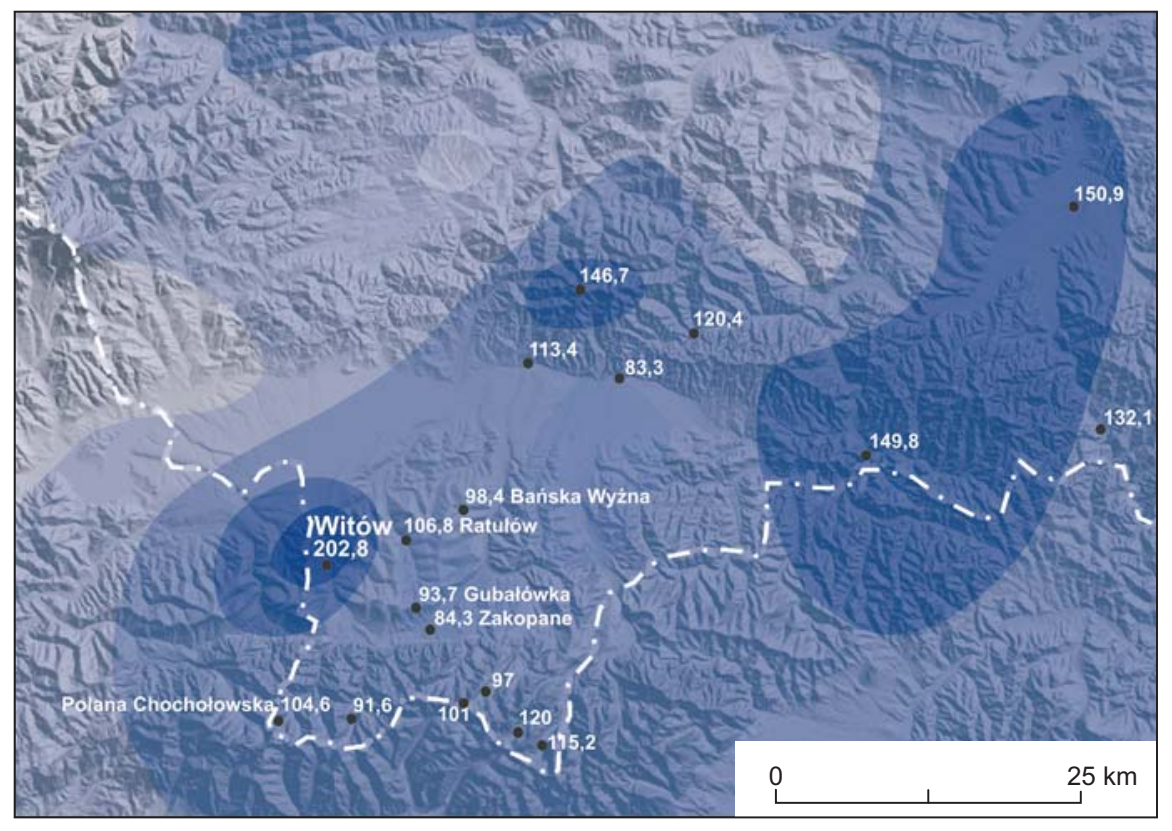

Ryc. 2. Opady atmosferyczne (suma w mm) w Małopolsce w dniach 22-28 czerwca 2009 r. Precipitation totals (in $\mathrm{mm}$ ) for the Małopolska region in the period 22-28 June 2009 inclusiv Źródło/Source: Analiza powodzi... (2009). 
w promieniu $12 \mathrm{~km} \mathrm{w}$ dniu 28 czerwca notowały opady dobowe nie większe niż $50 \mathrm{~mm}$. Pomimo małego prawdopodobieństwa wystąpienia tak wysokich opadów na obszarze Podhala (Cebulak, 1992), 5 czerwca 2007 r. miało miejsce podobne zdarzenie. W oddalonych od Witowa o niespełna $10 \mathrm{~km}$ dolinkach reglowych Tatr Zachodnich odnotowano opad o wysokości 140,2 mm w ciągu 45 minut (Gorczyca i Krzemień, 2008). Jego następstwem były duże przekształcenia rzeźby reglowych den dolin oraz stożków napływowych w rejonie doliny Kościeliskiej, Lejowej i Stanikowego Żlebu (Gorczyca i Krzemień, 2008).

Tabela 1. Opady dobowe 28.06.2009 r. w regionie Podhala

The 24-hour rainfall total for the Podhale region on 28.06.2009

\begin{tabular}{|c|c|c|}
\hline $\begin{array}{l}\text { Posterunek opadowy } \\
\text { Rainfall station }\end{array}$ & $\begin{array}{c}\text { Odległość od posterunku } \\
\text { w Witowie } \\
\text { Distance from rainfall station } \\
\text { in Witów } \\
(\mathrm{km})\end{array}$ & $\begin{array}{l}\text { Opad maksymalny } \\
28.06 .2009 \\
\text { Maximum rainfall } \\
(\mathrm{mm})\end{array}$ \\
\hline Gubałówka & 7,7 & 44,2 \\
\hline Polana Chochołowska & 11,8 & 32,0 \\
\hline Bańska Wyżna & 12,3 & 33,7 \\
\hline Ratułów & 7,0 & 49,0 \\
\hline Zakopane & 8,5 & 31,1 \\
\hline Witów & - & 140,0 \\
\hline
\end{tabular}

Opad burzowy z 28 czerwca 2009 r. oprócz zmian rzeźby spowodował zalanie wielu gospodarstw w Witowie (fot. 1). Zalaniu sprzyjało bardzo niekorzystne położenie domostw w dnie doliny Dunajca, pomiędzy nasypem drogowym a stokiem. Wezbrane wody potoków spływających ze zboczy Magury Witowskiej i Beskidu nie miały możliwości odpływu do Dunajca i rozlały się po szerokiej terasie. Do podtopień przyczyniła się również woda, która spłynęła bezpośrednio ze stoku. Gmina Kościelisko dostała z budżetu państwa 5 mln zł na likwidację szkód powstałych w następstwie tej powodzi.

\section{Morfologiczne skutki opadów na stokach}

Badania terenowe nie wykazały dużych powierzchniowych przekształceń na stokach - geomorfologiczne skutki opadów występowały głównie punktowo. Najliczniejsze były ślady spływu powierzchniowego w postaci położonych traw z pojedynczymi okruchami zwietrzeliny oraz w miejscach spłaszczeń $\mathrm{w}$ formie odsypów żwirowych niewielkich rozmiarów (1 m długości) i drobnej frakcji do $5 \mathrm{~cm}$ (fot. 2). Najwyraźniej tego typu formy były widoczne w obrębie stoku nar- 


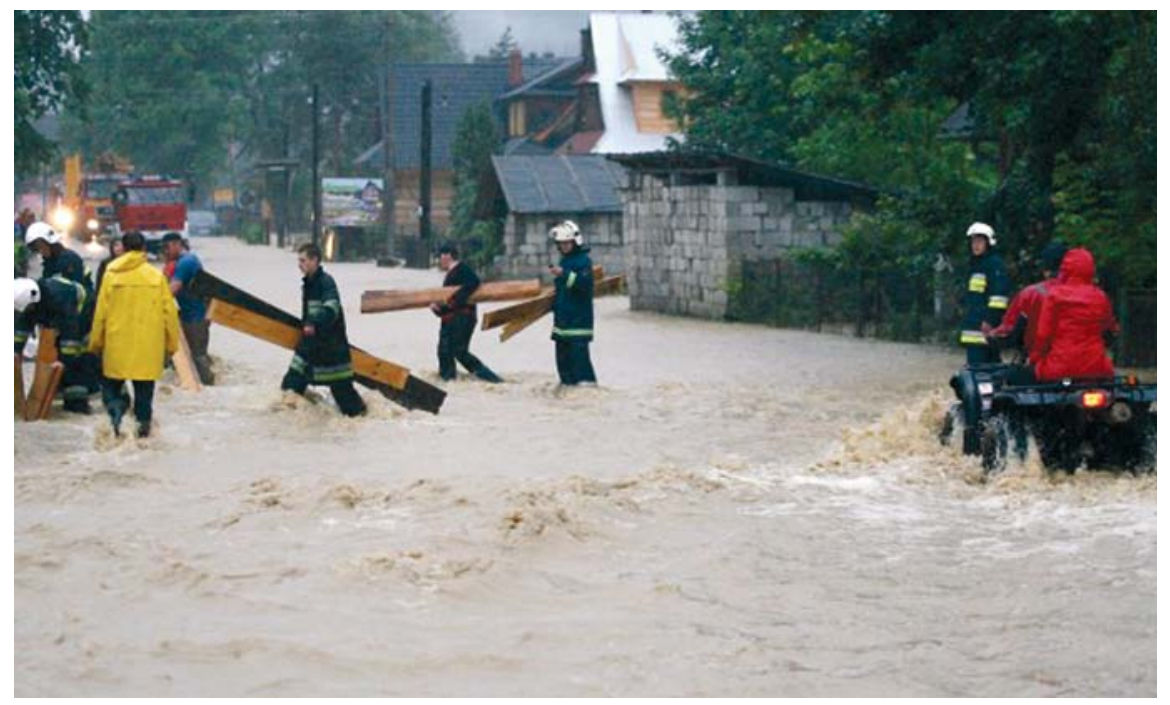

Fot. 1. Powódź w Witowie - 28.06.2009 r.

The flood in the village of Witów - 28.06.2009 Źródło/Source: http://fakty.interia.pl

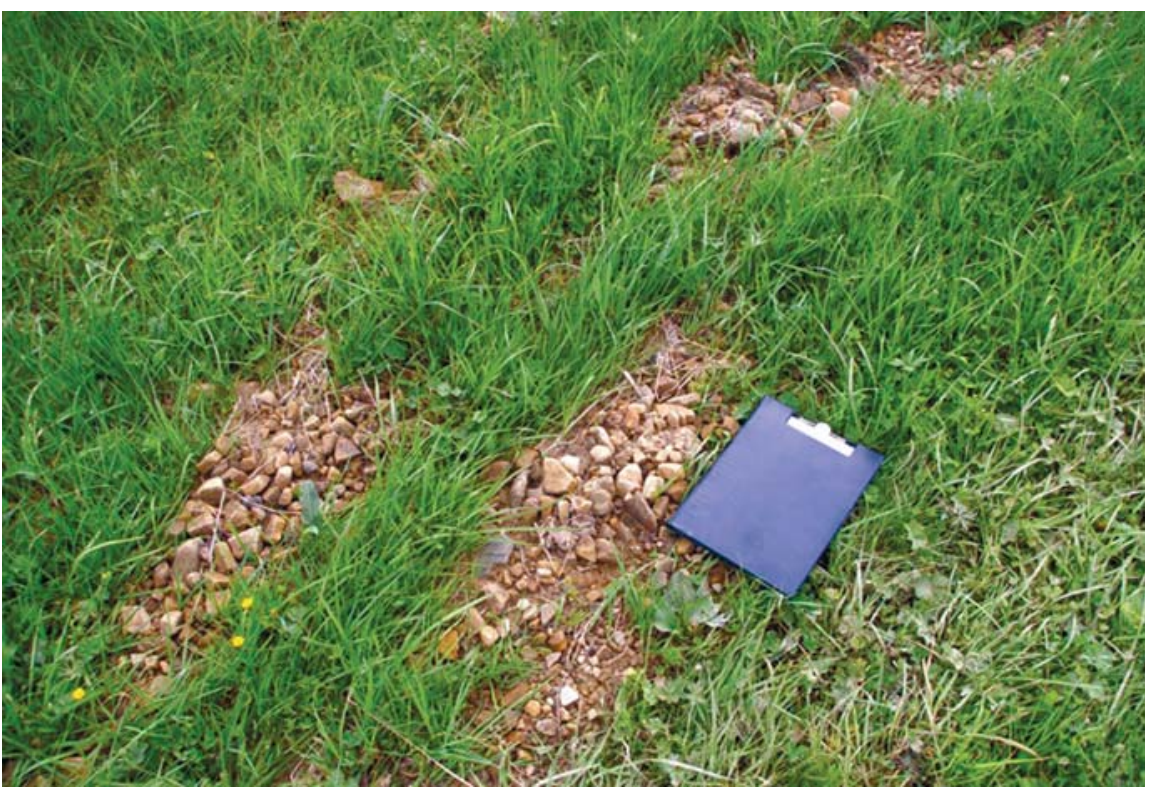

Fot. 2. Odsypy żwirowe na stoku (Fot. M. Dtugosz, także fot. 3-6)

Gravel deposition on a grass-covered slope (Phot. M. Dtugosz, the same as photo 3-6) 
ciarskiego w Witowie, gdzie na skutek prowadzonych prac melioracyjnych oraz wypasu owiec szata roślinna jest w dużym stopniu zubożona.

U podstawy stoków usypane zostały stożki napływowe o maksymalnej frakcji $15 \mathrm{~cm} \mathrm{z}$ przewaga frakcji drobnej (ryc. 3). Ich powierzchnia nie przekraczała kilku m² a miąższość osadów dochodziła do $10 \mathrm{~cm}$. Stożki tego typu powstały głównie w obrębie terasy nadzalewowej Dunajca u wylotu dróg polnych, które w trakcie wezbrania służyły jako linie odpływu. Na odcinkach o większym nachyleniu drogi zostały rozcięte rynnami erozyjnymi o głębokości do $50 \mathrm{~cm}$. W trakcie wezbrania nawet w obrębie starych i nieużytkowanych dróg występował transportu materiału o maksymalnej frakcji do $10 \mathrm{~cm}$.

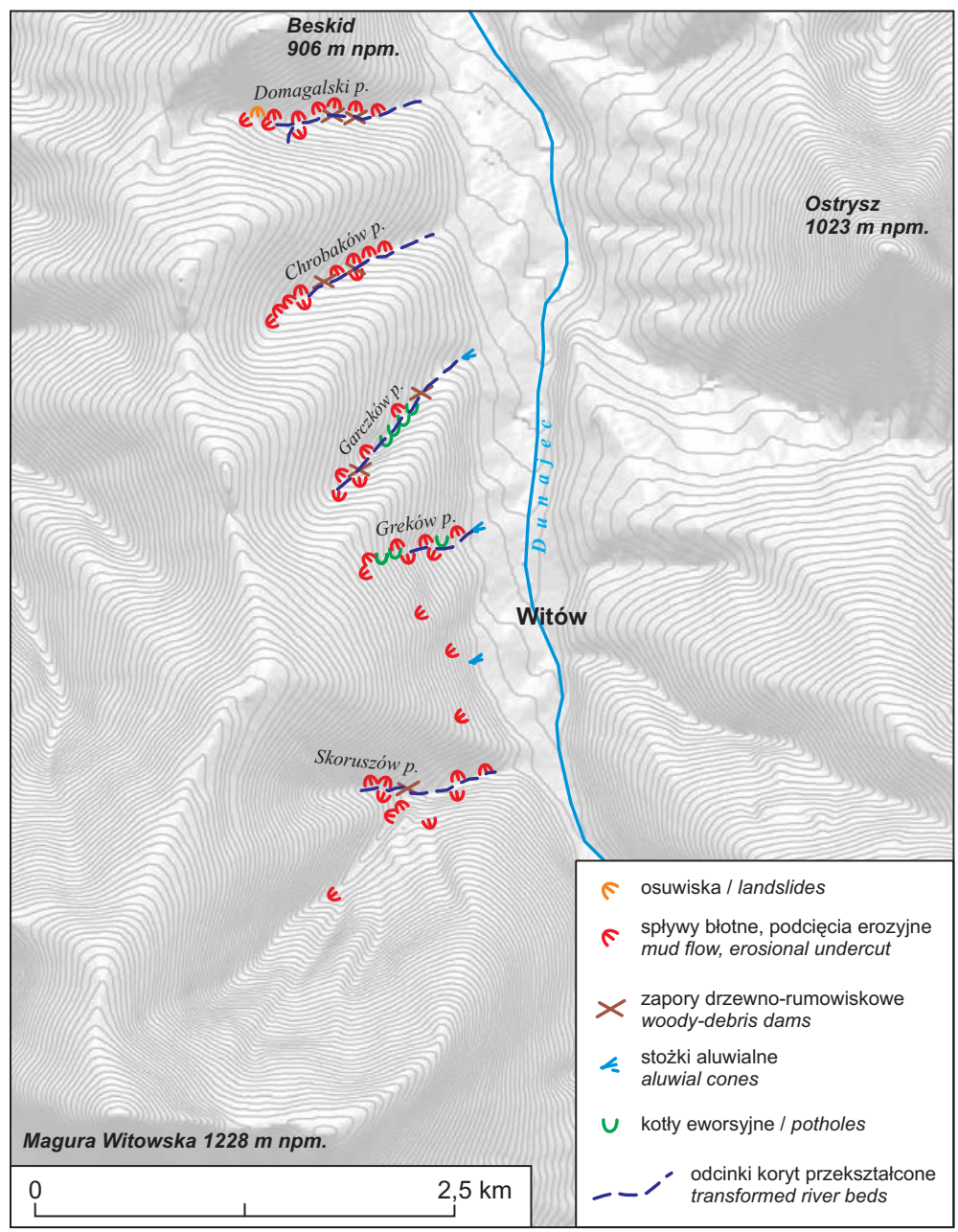

Ryc. 3. Formy powstałe w następstwie opadu burzowego 28.06.2009 r.

Relief forms arising out of the rainstorm on 28.06.2009

Opracowanie własne/Author's own elaboration. 
W badanym obszarze występuje szereg osuwisk różnego typu i wielkości. Strefa osuwisk ciągnie się pasem na długości $4 \mathrm{~km}$ wzdłuż doliny Czarnego Dunajca. Zsuwy występują tu w dolnych partiach zboczy doliny. Dominują płytkie zsuwy zwietrzeliny typu translacyjnego, rzadziej rotacyjnego. Osuwiska mają niewielkie rozmiary, do $180 \mathrm{~m}$ długości, $100 \mathrm{~m}$ szerokości, często niewyraźne skarpy, a ich powierzchnia nie przekracza 5 ha. Powstały na stokach o ekspozycji NE i E o nachyleniach do $10^{\circ}$. Są to osuwiska nieaktywne (Długosz, 2009). W trakcie opadu burzowego 28 czerwca formy te nie uległy odmłodzeniu. Wyjątek stanowią spływy błotne, uruchomione w obrębie skarp trzech osuwisk. Formy miały niewielkie rozmiary, średnio 4 m szerokości i 10 m długości. W następstwie opadów powstał jeden nowy zsuw zwietrzeliny w obrębie leja źródłowego Domagalskiego potoku (fot. 3). Jest to niewielka forma - szerokość u podstawy dochodzi do $35 \mathrm{~m}$, a długość nie przekracza $16 \mathrm{~m}$. Bezpośrednią przyczyną ruchów osuwiskowych, oprócz przepojenia pokryw wodą, było podcięcie zbocza przez wezbrany potok.

\section{Morfologiczne skutki opadów w korytach}

Przeprowadzone badania wykazały znacznie większe niż na stokach przekształcenia rzeźby w systemie korytowym oraz na zboczach w bezpośredniej bliskości koryt. Badania pozwoliły na wydzielenie kilku stref morfodynamicznych w profilu podłużnym omawianych dolin, różniących się rodzajem oraz stopniem natężenia procesów erozji i akumulacji. Doliny te mają zbliżone parametry morfometryczne. Charakteryzuje je niewielki spadek, od 8\% do $12 \%$. Mają przebieg na ogół prosty, a ich długość nie przekracza $2 \mathrm{~km}$. Podobny jest w nich rozkład odcinków morfodynamicznych; możemy wydzielić trzy takie strefy (ryc. 4). Odcinek górny - A obejmował obszar leja źródłowego oraz najwyżej położony odcinek doliny. Cechował się przewagą erozji wgłębnej nad akumulacją. Z uwagi na małą siłę erozyjną w tej części doliny przekształcenia były niewielkie, a rozcięcia w korycie nie przekraczały $60 \mathrm{~cm}$.

Zdecydowanie większe zmiany nastąpiły w odcinku środkowym - B. Strefy erozji dennej występują tutaj na przemian z akumulacją. Na podstawie rozmiarów form można wnioskować o większej sile erozyjnej w tej części doliny. W wielu odcinkach koryta powstały rynny erozyjne, w miejscach występowania mało odpornych łupków wcięte do głębokości 1,5 m (fot. 4). W środkowej części doliny, na całej jej długości miała miejsce również erozja boczna. Szczególnie predysponowane do podcinania zboczy były kręte odcinki oraz miejsca łączenia się kilku mniejszych dolin, gdzie siła erozyjna była największa. W tych sektorach powstawały podcięcia erozyjne wysokości dochodzącej do $4 \mathrm{~m}$ i długości do $20 \mathrm{~m}$. Poniżej stref erozyjnych występowały na ogół rejony akumulacji rumowiska oraz materiału żwirowego. Łachy żwirowe, o zróżnicowanej wielkości, niejednokrotnie wypełniały całe koryto na długości $100 \mathrm{~m}$. Średnica materiału 
transportowanego w trakcie wezbrania była zróżnicowana (ryc. 5). W górnej i środkowej części koryta dominowała frakcja gruba, 60-40 cm, a miejscami wezbrany potok transportował głazy o średnicy $1 \mathrm{~m}$; wartości te są zbliżone do notowanych podczas podobnego zdarzenia w dniu 5 czerwca 2007 r. w Tatrach Reglowych (Gorczyca i Krzemień, 2008). W dolnej części średnica materiału nie przekraczała $30 \mathrm{~cm}$.

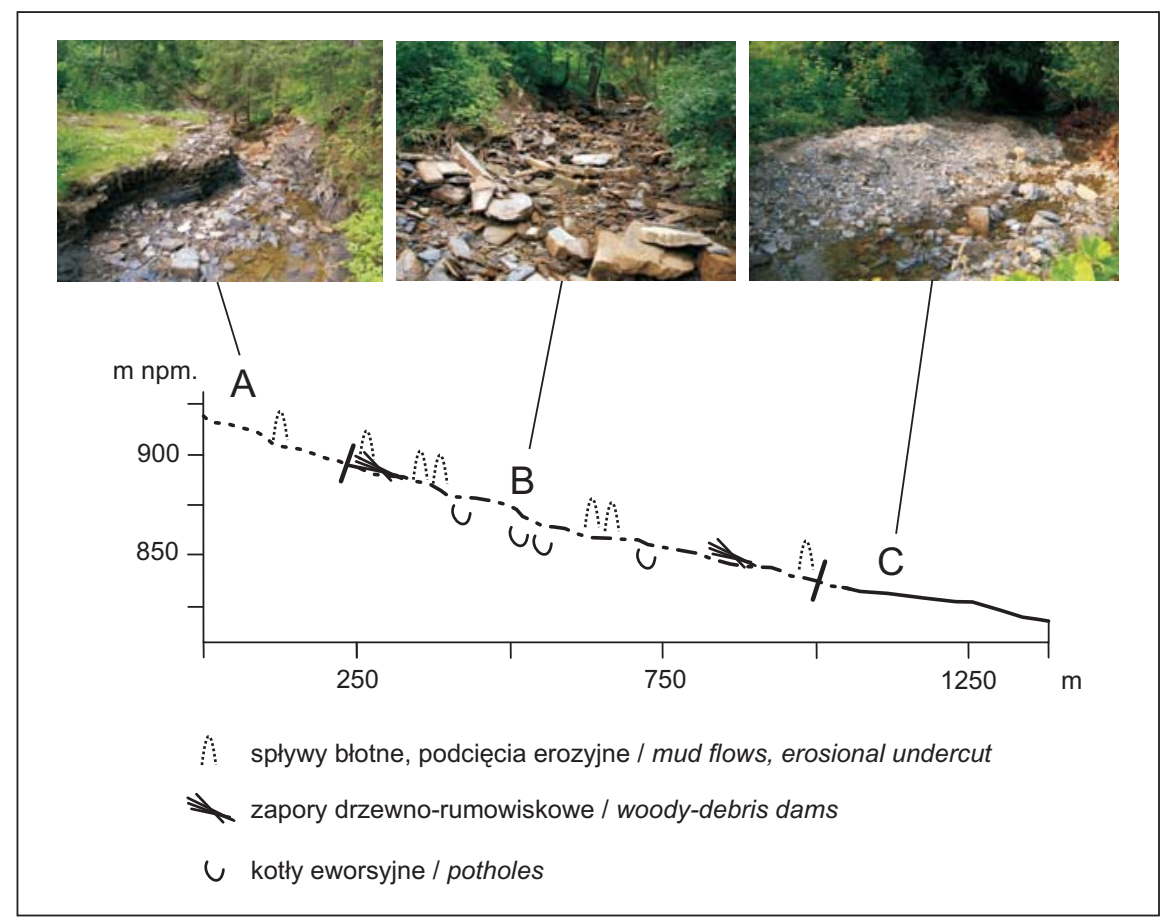

Ryc. 4. Profil podłużny potoku Garczków z zaznaczonymi strefami morfodynamicznymi.

A, B, C - objaśnienia w tekście

Longitudinal profile of the Garczków stream with morphodynamic zones.

A, B, C - as explained in text

Opracowanie własne/Author's own elaboration.

Dużą rolę w powstawaniu łach rumowiskowo-żwirowych odgrywały zatory drzewne oraz przepusty drogowe. Zapory zbudowane z rumoszu drzewnego tworzyły się głównie na skutek licznych spływów zwietrzeliny oraz podcięć erozyjnych na zboczach doliny w bezpośredniej bliskości koryta. Szacuje się, że $\mathrm{w}$ trakcie wezbrania powalonych zostało kilkadziesiąt drzew. Powyżej zatorów tworzyły się łachy żwirowe wypełniające całe koryto (ryc. 6). Poniżej, odciążone wody nabierały dużej siły erozyjnej, co sprzyjało erozji wgłębnej i bocznej na tych odcinkach. Podobna zależność dotyczy przepustów drogowych, które w trakcie 
wezbrania szybko traciły drożność stanowiąc naturalną tamę dla wezbranego potoku (fot. 5). W niektórych przypadkach dochodziło do ich niszczenia, co świadczy o bardzo dużej sile erozyjnej wezbranych wód.

Najniżej położona strefa morfodynamiczna C obejmowała dolne odcinki dolin, z mniejszym spadkiem. Dominowała tu akumulacja w postaci łach żwirowych o mniejszej powierzchni niż w odcinku środkowym. Najgrubsza frakcja materiału deponowanego miała średnicę poniżej $20 \mathrm{~cm}$.

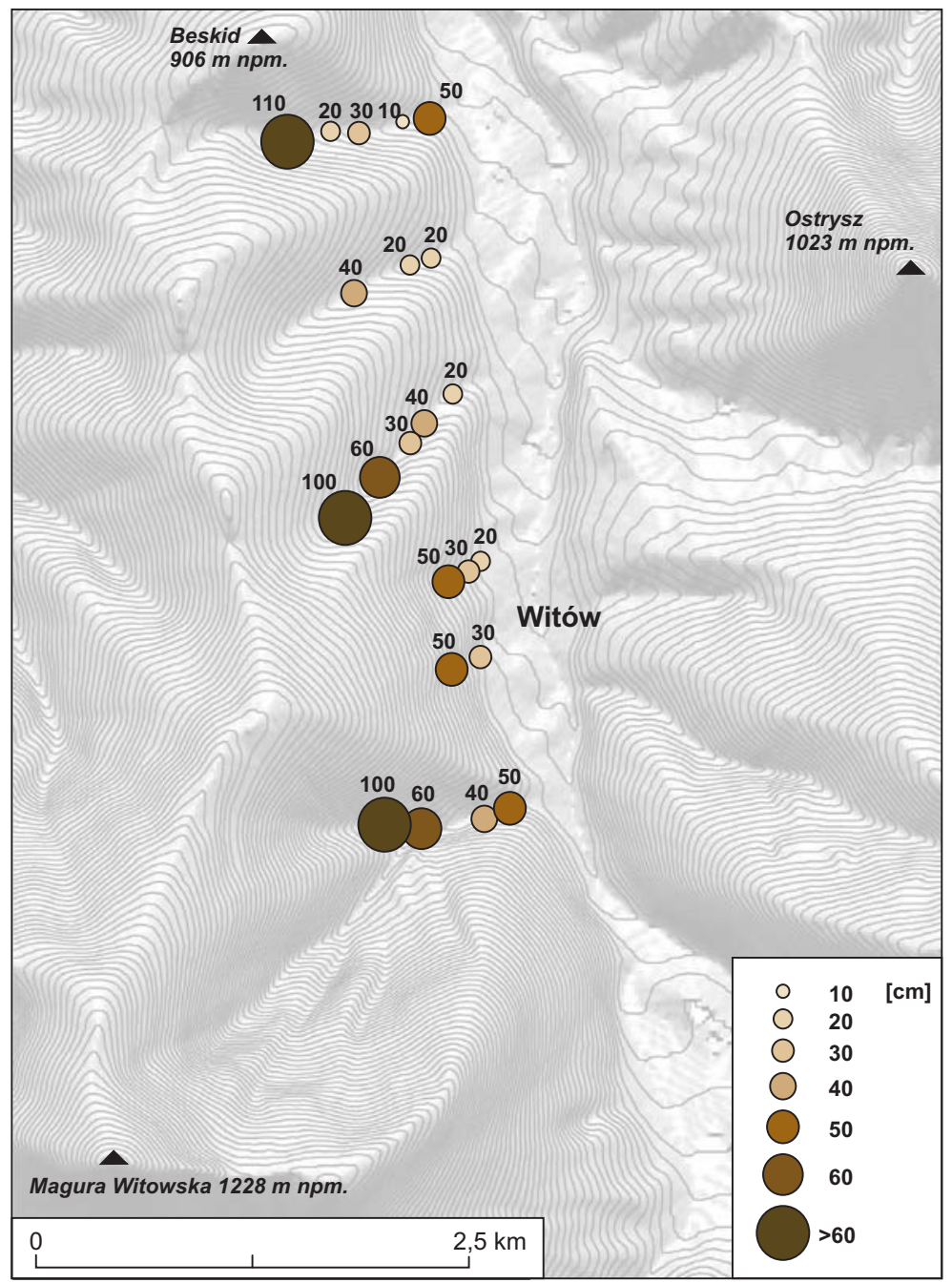

Ryc. 5. Frakcja maksymalna transportowana w trakcie powodzi Maximal fraction diameter of material transported during flood Opracowanie własne/Author's own elaboration. 
Opisany wyżej schemat nie wystąpił jedynie w dolinie potoku Chrobaków, gdzie rozmiary erozji i akumulacji w korycie są znacznie mniejsze. Wynika to prawdopodobnie z obecności na tym obszarze warstw piaskowcowych o większej miąższości. Praktycznie nie ma tu rynien erozyjnych, a na odpornych piaskowcach o małym upadzie wykształciły się kotły eworsyjne. Znacznie mniejsza erozja boczna i wgłębna spowodowała występowanie mniejszych stref akumulacji materiału. W pozostałych dolinach w podłożu przeważają mniej odporne na erozję warstwy łupkowe, dlatego transformacja rzeźby była większa.

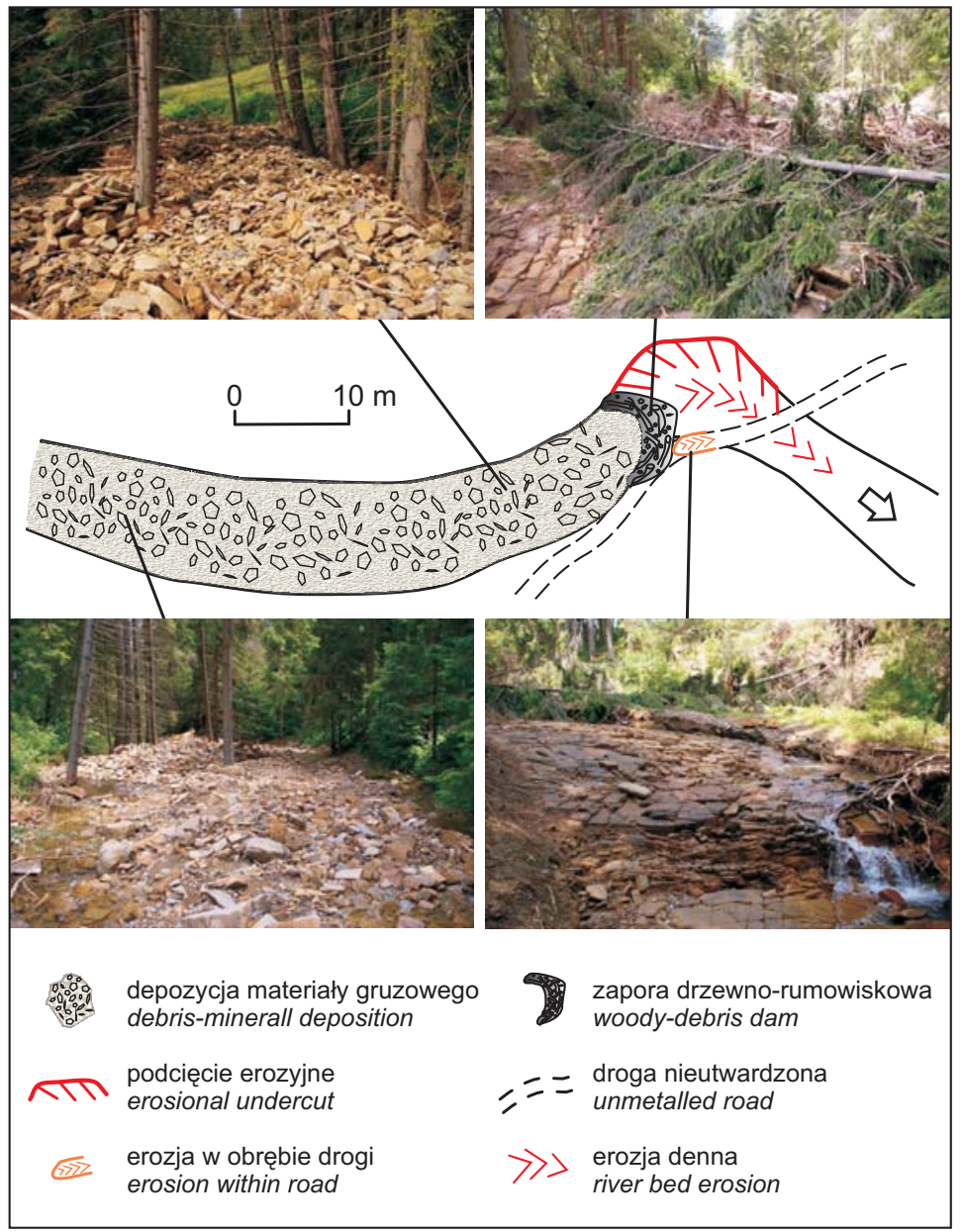

Ryc. 6. Szkic geomorfologiczny fragmentu koryta Skoruszów Geomorphological sketch of part of the Skoruszów stream Opracowanie własne/Author's own elaboration. 
Spośród wymienionych odcinków morfodynamicznych zdecydowanie najdłuższy był odcinek środkowy. Tam też zmiany w korycie były największe. We wszystkich dolinach znaczny udział w przekształcaniu zboczy miały spływy zwietrzeliny oraz erozja boczna potoków. Ogółem na całym obszarze powstały 34 formy, głównie spływy błotne i podcięcia erozyjne. Miały one niewielkie rozmiary: średnio $4 \mathrm{~m}$ szerokości i $8 \mathrm{~m}$ długości w przypadku spływów błotnych oraz odpowiednio $6 \mathrm{~m}$ i $4 \mathrm{~m}$ w przypadku podcięć erozyjnych. Spływy błotne powstawały zazwyczaj w strefie załomu pomiędzy stokiem a stromym zboczem doliny oraz na zboczu w strefie przykorytowej.

Opad nawalny spowodował na wybranych odcinkach bocznych dolinek wciosowych silną erozję wgłębną w środkowych partiach i akumulację materiału w części dolnej. Efektem tego były stożki napływowe zlokalizowane u ich wylotu zbudowane z rumoszu skalnego o frakcji maksymalnej do $30 \mathrm{~cm}$ (fot. 6). Formy te miały zróżnicowane rozmiary w zależności od wielkości doliny i nie przekraczały 4 m szerokości u podstawy oraz 4 m wysokości.

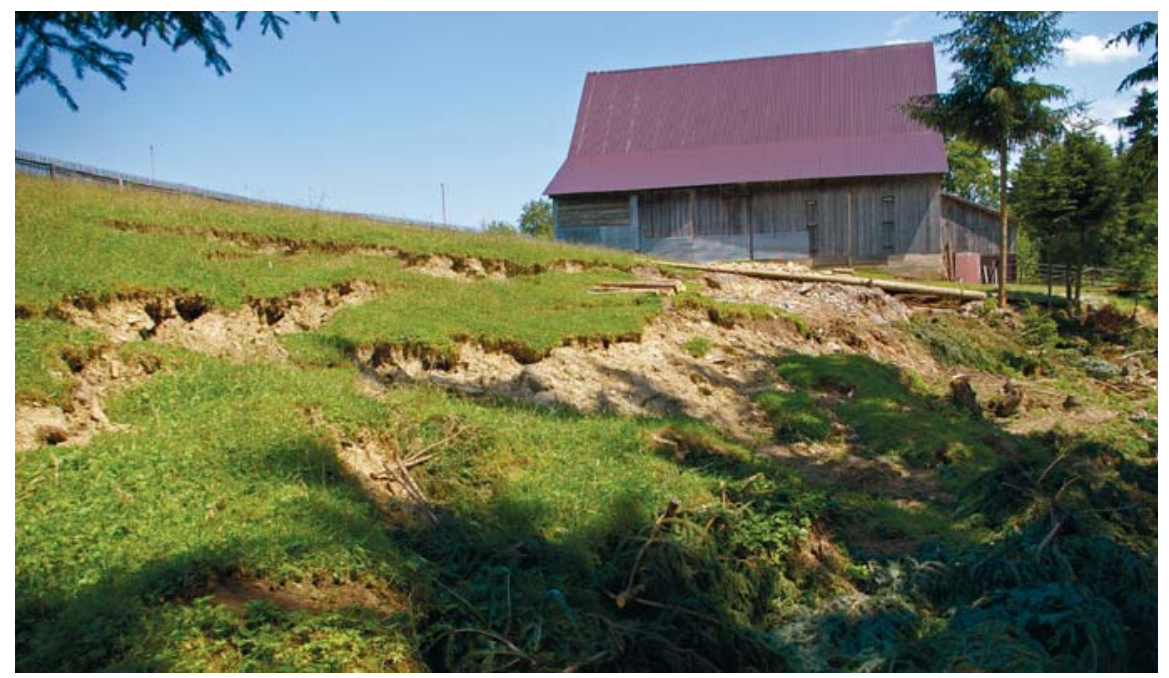

Fot. 3. Płytkie osuwisko zwietrzelinowe powstałe 28.06.2009 r. w górnych partiach Domagalskiego potoku

A shallow landslide occurring in the upper part of the Domagalski stream - 28.06.2009 


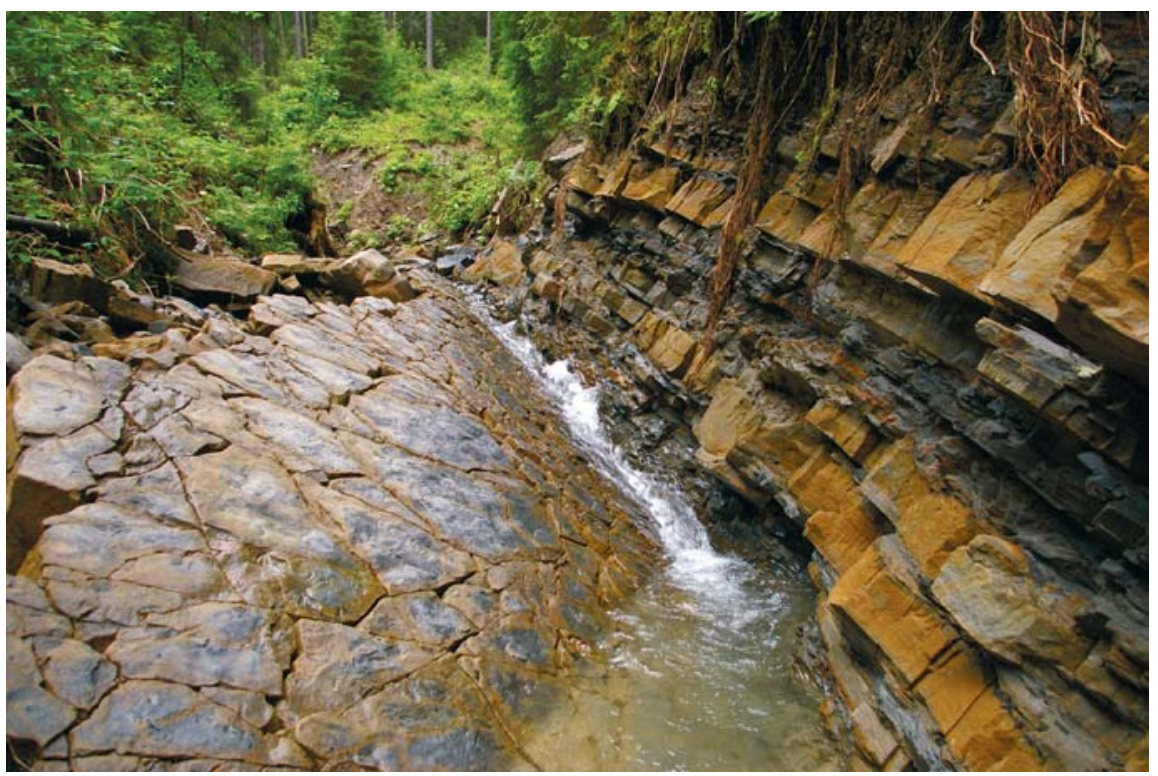

Fot. 4. Rynna erozyjna w środkowym odcinku potoku Skoruszów

Erosion gully in the middle section of the Skoruszów stream

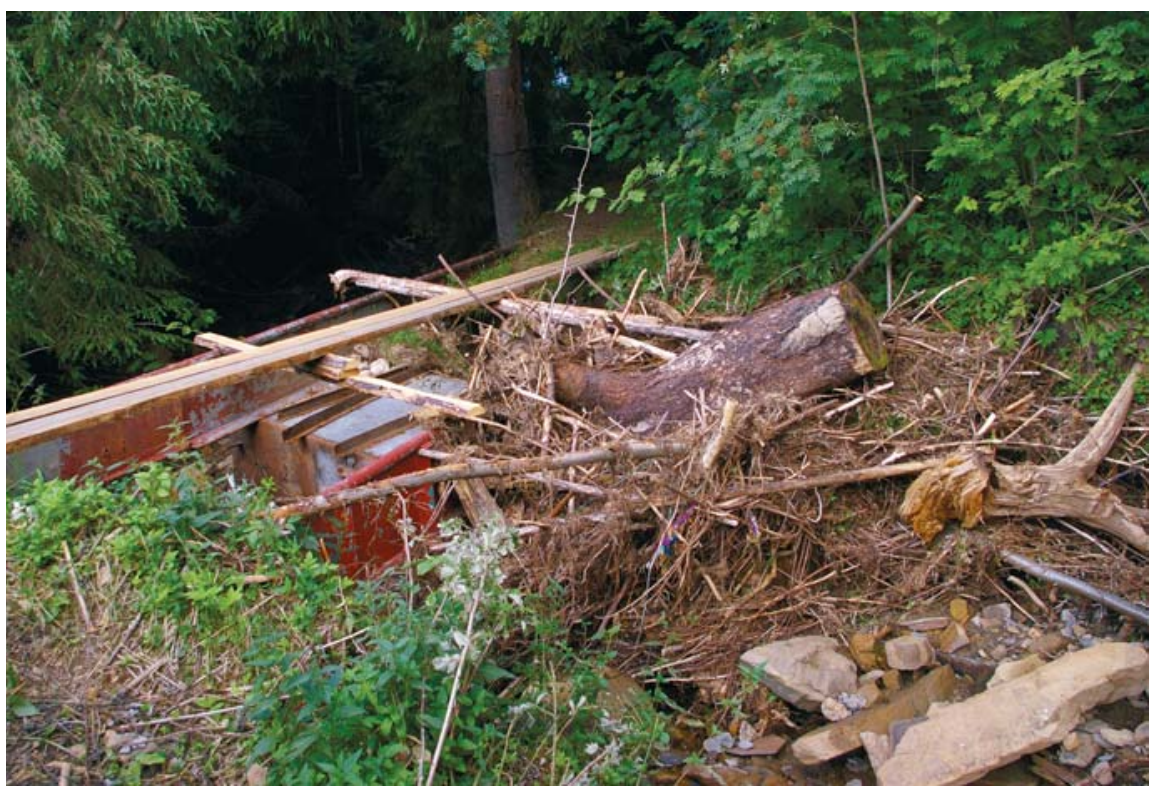

Fot. 5. Zablokowany przepust drogowy i zniszczony mostek - Chrobaków potok Blocked road culvert and damaged bridge - over the Chrobaków stream 


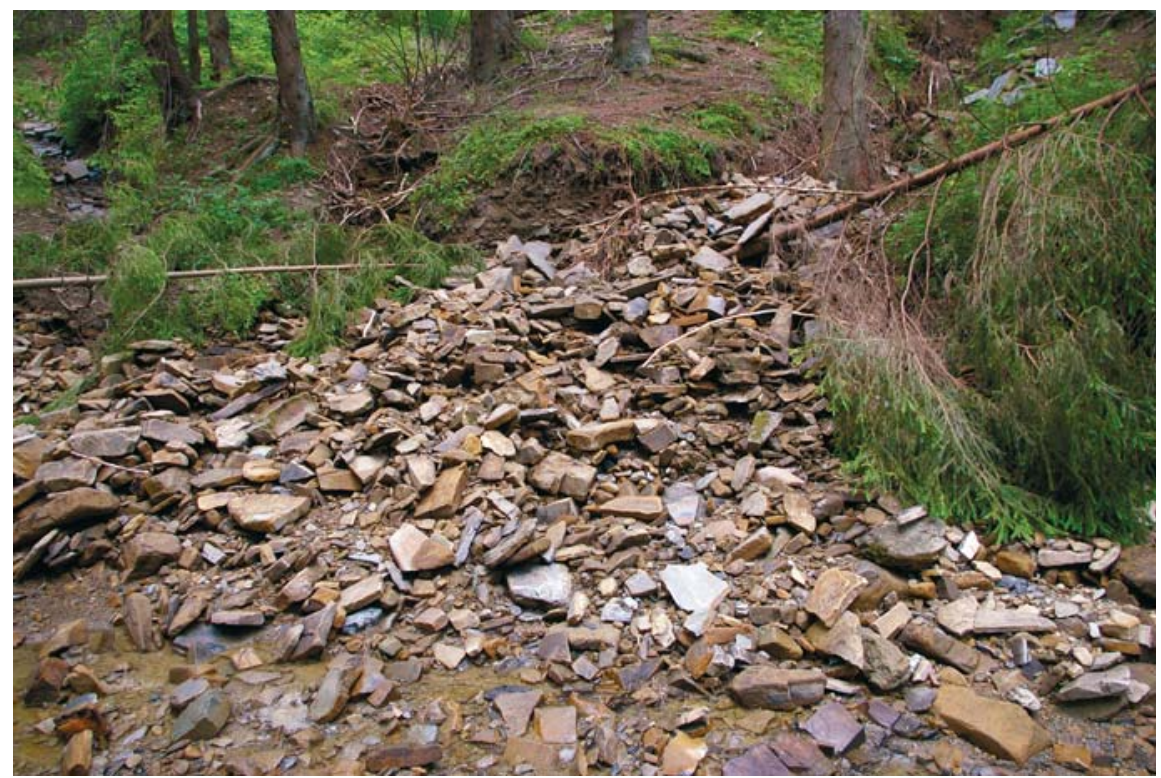

Fot. 6. Stożek gruzowy u wylotu dolinki wciosowej - potok Skoruszów

Debris cone formed at the outlet of the small V-shaped valley of the Skoruszów stream

\section{Wnioski}

W następstwie gwałtownych opadów burzowych w czerwcu 2009 r. system korytowy dolin odwadniających zbocza Magury Witowskiej i grzbietu Beskidu uległ silnemu przekształceniu. Największe zmiany zaobserwowano w środkowych odcinkach koryt w miejscach łączenia się mniejszych dolin bocznych. W odróżnieniu od den dolin i koryt, na stokach opad nawalny nie przyniósł większych skutków morfologicznych. Obserwacje terenowe potwierdziły stwierdzoną przez L. Starkla (1996) prawidłowość dotyczącą większej roli opadów nawalnych w modelowaniu koryt względem powierzchni stoków. Systemy korytowe charakteryzuje dużo szybsza reakcja na tego typu opady. W przypadku stoków, do uruchomienia procesów morfologicznych takich jak osuwanie potrzebne są opady przygotowujące o małym natężeniu, powodujące nasączenie pokryw wodą. Dopiero wtedy, przy wystąpieniu opadów burzowych o wysokiej sumie i natężeniu, powstają spływy i zsuwy oraz odmłodzeniu ulegają stare osuwiska (Gil, 1997; Kotarba, 1998; Gorczyca, 2004; Gil i Długosz, 2006).

Dużą rolę w modelowaniu koryt $\mathrm{w}$ trakcie wezbrania odegrały zapory drzewno-rumowiskowe, które stanowiły naturalne przeszkody dla transportowanego materiału i wody. Wpływały one w sposób istotny na dynamikę oraz rozkład 
przestrzenny stref erozji i akumulacji w korycie. Zapory drzewne oddziaływały również na stoki, doprowadzając w tych miejscach do większej erozji bocznej i podcinania zboczy. Powiązania systemu stokowego i korytowego są zjawiskiem często występującym w trakcie gwałtownych wezbrań na obszarze Karpat (Kotarba, 1998; Wyżga i inni, 2002-2003).

Podobną rolę w trakcie wezbrania odgrywały przepusty drogowe, które szybko traciły drożność stając się zaporą dla wezbranych wód. Prawidłowość tę potwierdzają wcześniejsze zdarzenia opadowe na Pogórzu oraz w Bieszczadach (Gorczyca i Wrońska-Wałach, 2008).

Skala zmian w korytach zaobserwowana w następstwie opadów w czerwcu 2009 r. oraz podobne zdarzenia hydro-meteorologiczne odnotowane w Karpatach pozwalają wnioskować o dużej roli morfologicznej opadów nawalnych w ewolucji rzeźby obszarów górskich (Gil i Starkel, 1979; Ziętara, 1998, 2005). Tak wysokie opady dobowe w rejonie Podhala mają prawdopodobieństwo wystąpienia rzędu 1-2 \% (Cebulak, 1992), ale w ostatnich latach ich częstość jest większa. Zdarzenia tego typu mają znaczenie w przekształcaniu rzeźby jedynie lokalnie, na obszarze objętym opadem. W skali całych Karpat znacznie większą rolę odgrywają deszcze rozlewne i tzw. pory deszczowe, w następstwie których dochodzi do zmian w korytach i na stokach na rozległych obszarach (Ziętara, 1968; Rączkowski i Mrozek, 2002; Gorczyca, 2004; Starkel, 2006).

\section{Piśmiennictwo}

Analiza powodzi w czerwcu 2009 r. na obszarze RZGW w Krakowie, 2009, http://oki.krakow.rzgw.gov.pl, strona internetowa Ośrodka Koordynacyjno-Informacyjnego Ochrony Przeciwpowodziowej, Regionalny Zarząd Gospodarki Wodnej w Krakowie (luty 2010 r.).

Badak J., 1964, Szczegótowa Mapa Geologiczna Polski w skali 1:50 000. Arkusz Czarny Dunajec M34-88D, Państwowy Instytut Geologiczny, Warszawa.

Bucała A., 2009, Rola opadów nawalnych w ksztattowaniu stoków i koryt w Gorcach na przykładzie zlewni Jaszcze i Jamne, Przegląd Geograficzny, 81, 3, s. 399-418.

Caine N., 1980, The rainfall intensity-duration control of shallow landslides and derbis flows, Geografiska Annaler, 62A, 1-2, s. 23-27.

Cebulak E., 1992, Maksymalne opady dobowe w dorzeczu górnej Wisty, Zeszyty Naukowe UJ, Prace Geograficzne, 90, Kraków, s. 79-96.

Cebulak E., Milanówka D., Malota A., Niedbała J., Pyrc R., Starkel L., 2009, Przebieg i skutki ulewy w dorzeczu górnego Sanu w dniu 26 lipca 2005 r., Materiały Badawcze - seria Meteorologia, Instytut Meteorologii i Gospodarki Wodnej, 40.

Długosz M., 2009, Modelowanie geosystemów polskich Karpat fliszowych przez ruchy masowe, Zakład Geomorfologii i Hydrologii Gór i Wyżyn IGiPZ PAN, Kraków, maszynopis.

Długosz M., Gębica P., 2008, Geomorfologiczne skutki oraz rola lokalnych ulew i powodzi w kształtowaniu rzeźby Pogórza Karpackiego (na przykładzie ulewy z czerwca 2006 r. w rejonie Sędziszowa Małopolskiego), Landform Analysis, 8, s. 13-20. 
Gil E., 1997, Meteorological and hydrological conditions of landslides in the Polish Flysch Carpathians, Studia Geomorphologica Carpatho-Balcanica, 31, s. 143-158.

Gil E., Długosz M., 2006, Threshold values of rainfalls triggering selected deep-seted landslide in the Polish Flysch Carpathians, Studia Geomorphologica Carpatho-Balcanica, 40, s. 21-43.

Gil E., Starkel L., 1979, Long-term extreme rainfalls and their role in the modelling of flysch slopes, Studia Geomorphologica Carpatho-Balcanica, 13, s. 207-220.

Gil E., Zabuski L., Mrozek T., 2009, Hydrometeorological conditions and their relation to landslide processes in the Polish Flysch Carpathians (an example of Szymbark area), Studia Geomorphologica Carpatho-Balcanica, 43, s. 127-143.

Glade T., 1998, Establishing the frequency and magnitude of landslides - triggering rainstorm events in New Zealand, Environmental Geology, 35, 2/3, s. 160-174.

Gorczyca E., 2004, Przeksztatcenie stoków fliszowych przez procesy masowe podczas katastrofalnych opadów (dorzecze Łososiny), Wydawnictwo Uniwersytetu Jagiellońskiego, Kraków.

Gorczyca E., Krzemień K., 2008, Morfologiczne skutki ekstremalnego zdarzenia opadowego w Tatrach Reglowych w czerwcu 2007 r., Landform Analysis, 8, s. 21-24.

Gorczyca E., Wrońska-Wałach D., 2008, Transformacja matych zlewni górskich podczas opadowych zdarzeń ekstremalnych, Landform Analysis, 8, s. 25-28.

Govi M., Sorzana P., Tropeano D., 1982, Landslide mapping as evidence of extreme regional events, Studia Geomorphologica Carpatho-Balcanica, 15, s. 43-61.

Jakubowski K., 1965, Wptyw pokrycia roślinnego oraz opadów atmosferycznych na powstawanie osuwisk zwietrzelinowych, Przegląd Geologiczny, 9, 3, s. 395-398.

Kotarba A., 1992, Denudacja mechaniczna Tatr Wysokich pod wptywem opadów ulewnych, Prace Geograficzne, IGiPZ PAN, 155, Warszawa, s. 191-208.

-, 1994, Geomorfologiczne skutki katastrofalnych letnich ulew w Tatrach Wysokich, Acta Universitatis Nicolai Copernici, Geographia, 27, 92, s. 21-34.

-, 1998, Morfogenetyczna rola opadów deszczowych w modelowaniu rzeźby Tatr podczas letniej powodzi w roku 1997, [w:] Z badan fizycznogeograficznych w Tatrach III. Dokumentacja Geograficzna, 12, s. 9-23.

-, 2002, Wspótczesne przemiany przyrody nieożywionej w Tatrzańskim Parku Narodowym, [w:] Przemiany środowiska przyrodniczego Tatr, red. W. Borowiec, A. Kotarba, A. Kownacki, Z. Krzan, Z. Mirek, Tatrzański Park Narodowy, Polskie TPN Oddział w Krakowie, Instytut Botaniki PAN, Kraków-Zakopane, s. 13-19.

Krzemień K., 1988, The dynamics of debris flows in the upper part of the Starorobocianska Valley (Western Tatra Mts.), Studia Geomorphologica Carpatho-Balcanica, 22, s. 123-144.

Łajczak A., Migon P., 2007, The 2002 debris flow in the Babia Góra Massie - implications for the interpretation of mountainous geomorphic systems, Studia Geomorphologica Carpatho-Balcanica, 41, s. 97-116.

Micu M., Balteanu D., 2009, Landslide hazard assessment in the Curvature Carpathians and Subcarpathians, Romania, Zeitschrift fuer Geomorphologie, 53, Supplementary Issue 3, Berlin-Stuttgart, s. 31-47.

Midriak R., 1984, Debris flows and their occurence in the Czechoslovak Carpathians, Studia Geomorphologica Carpatho-Balcanica, 18, s. 135-149.

Nemćok A., 1982, Zosuvy v Slovenskych Karpatach, Veda, Bratislava.

Rączkowski W., Mrozek T., 2002, Activiting of landsliding in the Polish Flysch Carpathians by the end of the 20th century, Studia Geomorphologica Carpatho-Balcanica, 36, s. 91-111. 
Starkel L., 1996, Geomorphic role of extreme rainfalls in the Polish Carpathians, Studia Geomorphologica Carpatho-Balcanica, 30, s. 21-39.

-, 2006, Geomorphic hazards in the Polish flysch Carpathians, Studia Geomorphologica Carpatho-Balcanica, 40, s. 7-19.

Thiel K., 1989, Kształtowanie fliszowych stoków karpackich przez ruchy masowe - na przyktadzie badań na stoku Bystrzyca w Szymbarku, Prace Instytutu Budownictwa Wodnego PAN, Gdańsk, 17.

Wyżga B., Kaczka R.J., Zawiejska J., 2002-2003, Gruby rumosz drzewny w ciekach górskich - formy wystepowania, warunki depozycji i znaczenie środowiskowe, Folia Geographica, Series Geographica Physica, 33-34, s. 117-138.

Ziętara T., 1968, Rola gwattownych ulew i powodzi w modelowaniu rzeźby Beskidów, Prace Geograficzne, IG PAN, 60.

-, 1998, Geomorfologiczne skutki ulewy 9 lipca 1997 r. w Beskidzie Wyspowym i Sadeckim na tle powodzi w Karpatach fliszowych, [w:] K. Pękala (red.), Gtówne kierunki badan geomorfologicznych w Polsce, stan aktualny i perspektywy, Wydawnictwo UMCS, Lublin, s. 211-223.

[Wpłynęło: marzec; poprawiono: sierpień 2010 r.]

\section{MICHAŁ DŁUGOSZ}

\section{THE ROLE OF EXTREME FALLS OF RAIN IN THE TRANSFORMATION OF CARPATHIAN RELIEF} (A CASE STUDY FROM POLAND'S PODHALE REGION, JUNE 2009)

Rainfalls are among the most important factors controlling morphological processes in mountain areas. The geomorphic effect of falls of rain is known to depend on their duration and intensity, as well as on the amount of precipitation involved. Also exerting a critical impact are the conditions of such environmental components as relief, geology and land use.

A series of high-intensity rainfall events took place at the end of June 2009 and led to local downpours on the upper Vistula catchment. These were initiated by the shortduration, highly localised and very high intensity rainstorms occurring in southern Poland between 22nd and 28th June. The maximum 24-hour rainfall total in this case was $140 \mathrm{~mm}$, as recorded in the Podhale region near the village of Witów. This paper presents the morphological effects of this extreme rainfall event.

Field study was carried out over an area of some $12 \mathrm{~km}^{2}$ between Magura Witowska and the Krowiarki Ridge, as situated in the Gubałówka foothills of the Polish Carpathians. Geomorphological mapping was based on topographic maps at 1:10 000 scale and GPS. Erosion and accumulation forms caused by extreme rainfall were recognized and marked on the map. The maximal fraction diameter of transported material was checked along the longitudinal profile of each local mountain stream.

The greatest morphological changes were to be recorded in all river beds within the study area. On the basis of field observation, it was possible to discern three morphodynamic zones along the longitudinal profile of each mountain stream. These were: the upper zone with small bed and lateral erosion without accumulation forms; the central 
zone with a high rate of bed and lateral erosion and with accumulation sections including gravel and debris material; and the bottom zone with accumulation forms such as debris bars. The most intensive processes were found to have taken place in the central parts of the channels. The dominant fraction diameter of material transported in this section was between 40 and $60 \mathrm{~cm}$, albeit with single moved boulders exceeding $1 \mathrm{~m}$ in diameter. Many earth slumps and erosion undercuts appeared along valley slopes close to river beds.

The high-intensity rainfall activated neither slope systems nor river channels. Even the old landslides of which there are many in the study area, were not activated. Only a few earth slumps appeared within the scarps of old landslides. Linear erosion occurred along old, unused roads located on steep slopes. Indeed, alluvial fans appeared at the bottom of the slopes where roads pass through alluvial terrace.

Natural wood debris dams and road culverts played an important role in the transformation of river channels during the downpour. In zones situated above them, rivers built debris bars which occupied even the whole river-bed at $100 \mathrm{~m}$ longwise. Below fans, the deloaded mass of waters had high erosion potential, with the result that beds and banks were damaged.

The enormity of the river-bed transformation occurring during the June 2009 downpour and other similar hydro-meteorological events recorded in the Carpathians points to the major role this kind of fall of rain can play in a mountain denudation system. 